\title{
Biotechnology Research in an Age of Terrorism*
}

\author{
By the Committee on Research Standards and Practices to Prevent the Destructive Application \\ of Biotechnology, National Research Council
}

Reviewer: Ademola Victor Akinyoade

Submission: July 2011

Accepted: August 2011

Published: November 2011

\section{Keywords}

biosecurity, biodefense, biowarfare, bioterrorism, dual use

\section{INTRODUCTION}

This book is a report by the Committee on Research Standards and Practices to Prevent the Destructive Application of Biotechnology. The Committee, chaired by Gerald R. Fink, a Professor of Genetics, was set up by the US National Research Council to “...consider ways to minimize threats from biotechnological warfare and bioterrorism without hindering the progress of biotechnology, which is essential for the health of the nation." (p. 1). It addresses the dual-use nature of biotechnology. Dual-use refers to a situation in which materials, technologies and knowledge intended for human betterment can be misused to harm humans by creating weapons for biological warfare (BW) and biological terrorism (BT). Peace scholars and practitioners, by the very nature of their work have a moral duty to familiarize themselves with the subject of this book and make the dual-use concept a general feature of their teaching and activities.

\section{SUMMARY OF CONTENTS}

The report has six parts: four chapters, an executive summary and appendices. It opens with a succinct summary of the report, discussing the background of the dual-use exigency that led to the setting up of the Committee, and the definition of its focus and brief. It reviews the current and evolving regulatory environment of biotechnology in the US, and stresses the need to prevent inhibiting benign biotechnologies through overt restriction by current legislation. It calls for a harmonized international system, similar to the one being proposed for the US. Finally, it summarizes the proposed new system, including its seven recommendations and draws conclusions.

The introduction discusses the life sciences today, detailing the ever-expanding research activities and capabilities in genetic engineering, its myriad of applications in industry, agriculture and medicine, as well as the publications and the workforce involved in the endeavor. It traces the origin of modern biowarfare to antiquity and the foundation of recent developments in biotechnology to scientific discoveries in the late 19th and early 20th centuries. Germany, Japan, the US, Great Britain, Canada, France and the former Soviet Union all had some form of bio-weapon program during World War I and/or World War II. Despite the Biological and Toxins Weapon Convention (BTWC), the new dual-use threat is a result of the ease of acquiring biotechnology and BW capability, and the world-wide availability of equipment and expertise post-BTWC. 
Chapter two "reviews the US domestic and international rules, regulations, and institutional arrangements and processes that provide oversight of research on pathogens and potentially dangerous biotechnology within government laboratories, universities and other research institutions and industry" (p. 33). The US National Institutes of Health (NIH) took up the responsibilities of providing oversight for genetic engineering research based on advice from the 1975 Asilomar Conference. The NIH Guidelines and their sphere of application are presented in this chapter.

Chapter three discusses the control of information about biological research, reviewing the existing and emerging regulatory environment. It argues that the life sciences could learn from the dual-use experiences of two comparable areas: nuclear weapon technology in physics and cryptography in government. It contends that overt control and secrecy, and the vagueness of the categories of "sensitive" information may ultimately make the life sciences less inviting to American researchers and more attractive to foreigners. “...imposing mandatory information controls on research in the life sciences, if attempted, will be difficult and expensive with little likely gain in genuine security", it concludes (p. 101).

The final chapter presents the conclusions and recommendations of the Committee. It contains ways of enhancing the regulations for genetic research while allowing the essential activities of the scientific enterprise to continue (p. 33).

\section{RECOMMENDATIONS}

This proposed system "consists of a number of filters for research proposals and publication of results that would cumulatively serve to protect against potential misuse yet enable important research activities to go forward" (p. 110). The summaries of the recommendations are restated below.

1) "Educating the Scientific Community: we recommend that national and international professional societies and related organizations and institutions create programs to educate scientists about the nature of the dual-use dilemma in biotechnology and their responsibilities to mitigate its risks."

2) "Review of Plans for Experiments: we recommend that the Department of Health and Human Services (DHSS) augment the already established system for review of experiments involving recombinant DNA conducted by the National Institute of Health (NIH) to create a review of system for seven classes of experiments (Experiments of Concern, EoC) involving mi- crobial agents that raise concerns about their potential for misuse."

3) "Review at the Publication Stage: we recommend relying on self-governance by scientists and scientific journals to review publications for their potential national security risks."

4) "Creation of a National Science Advisory Board for Biodefense: we recommend that the Department of Health and Human Services create a National Science Advisory Board for Biodefense (NSABB) to provide advice, guidance, and leadership for the system of review and oversight we are proposing."

5) "Additional Elements for Protection against Misuse: we recommend that the federal government rely on the implementation of current legislation and regulation, with periodic review by the NSABB, to provide protection of biological materials and supervision of personnel working with these materials."

6) "A role for Life Sciences in Efforts to Prevent Bioterrorism and Biowarfare: we recommend that the national security and law enforcement communities develop new channels of sustained communication with the life sciences community about how to mitigate the risks of bioterrorism."

7) "Harmonized International Oversight: we recommend that the international policymaking and scientific communities create an International Forum on Biosecurity to develop and promote harmonized national, regional, and international measures that will provide a counterpart to the system we recommend for the United States."

\section{CONTRIBUTIONS}

This book is the first of its kind to deal specifically with the issue of national security and the life sciences, not only in the US but world-wide. The effort is justified by the discovery of nations with clandestine research programs dedicated to the creation of biological weapons, the anthrax attacks on US citizens in 2001, the rapid progress in biotechnology, and the easily accessible methods and materials for these new technologies.

The book recommends procedures and frameworks of internal and external overseeing for monitoring life science research with dual-use potential. The recommendations are relevant not only for the US but for the global community in an effort to counter the threat of biotechnology in the age of terrorism.

The immediate impact of the book is the adoption of its fourth recommendation by the US government, which 
established the National Science Advisory Board for Biosecurity (NSABB) to provide advice, guidance, and leadership for the system of review and proposed overseeing.

Historically, dual-use potential has not been fully appreciated by the life sciences and wider communities. However, the first recommendation, educating the scientific community, has led to the development of academic and non-academic education programs to raise awareness about the dilemma. Institutions such as the University of Bradford's Division of Peace Studies, the Federation of American Scientists, NSAAB, Resources for Research Ethics Education, provide information and offer education on the dual-use nature of biotechnology and its threats to peace at all levels. Consequently, life scientists, peace scholars and conflict resolution specialists are the main target audience for such programs.
The inclusion of peace scholars and practitioners is important, because educating the scientific community on the potential threats of biotechnology to world peace and security is essentially peace education. Peace education, rooted in peace studies, "is the process of teaching people about the threats of violence and strategies for peace," (Harris, 2008, p. 15). One can say that this is the book's most important contribution to the field of peace studies and practice. Biowarfare and bioterrorism are diametrically opposed to the values that peace studies are committed to: peace, nonviolence and sustainable development. Scholars and practitioners in the field will do well, therefore, to familiarize themselves with the book in order to contribute meaningfully to averting the threats of biowarfare and bioterrorism.

\section{Recommended citation}

AKINYOADE, Ademola Victor (2011). "Review of Biotechnology Research in an Age of Terrorism" [review online]. Journal of Conflictology. Vol. 2, Iss. 2, pp. 73-76. Campus for Peace, UOC. [Consulted: dd/mm/yy].

<http://www.uoc.edu/ojs/index.php/journal-of-conflictology/article/view/vol2iss2-akinyoade/vol2iss2akinyoade>

ISSN 2013-8857

(c) SOME RIGHIS RESERVED
This work is subject to a Creative Commons Attribution-Noncommercial-NoDerivative-Works 3.0 Spain licence. It may be copied, distributed and broadcasted provided that the author and the source (Journal of Conflictology) are cited. Commercial use and derivative works are not permitted. The full licence can be consulted at: $<$ http://creativecommons.org/licenses/by-nc-nd/3.0/es/deed.en> 


\section{About the author of the review}

\section{Ademola Victor Akinyoade}

demolaakinyoade@gmail.com

Ademola Victor Akinyoade is a doctoral candidate on the Peace and Conflict Studies programme, Institute of African Studies, University of Ibadan, Nigeria. He is a member of the Guild of Independent Scholars (Lagos Priory), Florida, USA, publisher of the Journal of Alternative Perspectives in the Social Sciences. He was the founding faculty member, pioneer Acting Program Coordinator and head of the Department of Peace and Development Studies at Salem University, Lokoja, Nigeria (2008-2011).

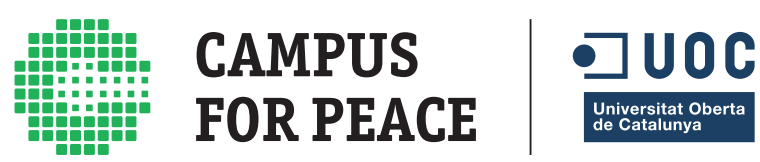

